\title{
Bacteria of the Clyde Sea Area: A Quantitative Investigation.
}

By

Blodwen Lloyd, M.Sc., Ph.D.,

From the Dept. of Bacteriology and Botany, Royal Technical College, Glasgov, and the Marine Biological Station, Millport.

With 7 Figures in the Text.

CONTENTS.

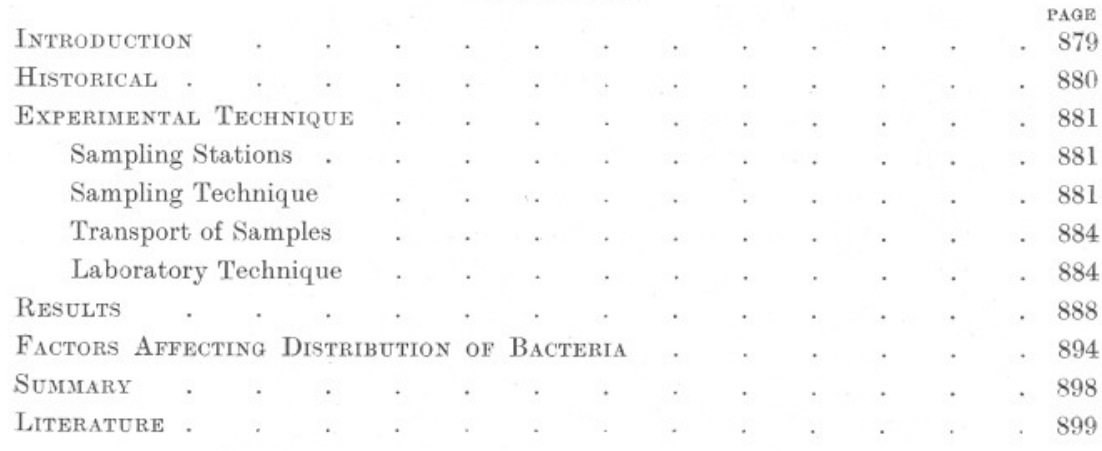

\section{INTRODUCTION.}

THE importance of bacterial action in the seas has long been recognised, but investigation in marine bacteriology lags behind that of corresponding terrestrial problems. Such general information about marine bacteria as is now available is derived mainly from bacteriological work of some decades ago. At that time the technique of the science was not fully developed, but at the present day it has become so specialised that it lies outside the province of the marine biologist, although he alone is able to appreciate the significance of bacteria in the general economy of the sea.

Whilst the part played by bacteria in the food-cycle of the sea depends partly upon special features in the metabolism of the various bacterial species, it obviously depends chiefly upon the abundance of such organisms. Now in an investigation of the numbers of bacteria in any sample, it is extremely important that due regard be paid to the conditions under which the work is performed. In much of the early work on marine bacteria the experimental methods are not described. Where such 
information is available, one finds that there is lack of uniformity in the experimental methods adopted, and that therefore the results of different workers are not readily comparable with one another. Standard routine methods are needed for the bacteriological examination of sea-water, such as are customary for the routine analysis of fresh water. It is significant that among the various bacteriological handbooks on the technique of water-examination, none that has come to the writer's notice gives consideration to the special aspects of marine bacteriology.

It is the purpose of this paper to present a quantitative report on the marine bacteria of the Clyde Sea Area. This report is based on observations carried out over a period of 18 months, standardised routine methods having been devised for taking the samples and for laboratory technique.

\section{HisTORICAL.}

The earliest numerical record of marine bacteria appears to be that of Sanfelice (see Bertel, 5), who found in 1889 that the number of organisms in the sea decreased as the distance from the shore increased. From this he deduced that bacteria in the sea were not native to it, but terrigenous, "apportées à la mer avec les ordures." This prompted de Giaxa (11) to investigate the viability of pathogenic organisms in seawater. He found that they flourished in sterile sea-water but did not survive competition with other forms in unsterilised sea-water-a finding that has been confirmed in more recent years by the Royal Sewage Commission (16). Russel (21), who analysed samples from the Gulf of Naples and the Atlantic, observed that the number of bacteria decreased from the surface down to 200 metres; he also noted that marine mud contained many more bacteria than the water immediately above. Schmidt-Nielsen (23), however, found the reverse to hold, obtaining for northern waters an average of 26 bacteria per c.c. at the surface and 420 per c.c. at 25 metres.

Fischer's report (10), which is based on samples taken by the German Plankton Expedition of 1889, is the most comprehensive account of marine bacteria. He gave full accounts of technique employed and furnished descriptive and statistical analyses of the water samples obtained. His results vary very much, but in general he found that there were fewer bacteria at greater depths than at the surface. $\mathrm{He}$ noted also that the numbers were greater at sunrise than in the afternoon.

The Prince of Monaco made some analyses of the Atlantic sea-water, and found the bacterial content to be extremely high between the Azores and Portugal (see Bertel, 5); this he attributed to the existence of a submarine ridge with very rich fauna.

In 1911 Bertel (5) investigated the bacteria of the sea-water off Monaco, 
and found (1) that the number of bacteria diminished progressively from coastal areas outwards, (2) that the number of bacteria increased from the surface downwards, and (3) that the number at the surface increased during the night, and diminished during the early hours of the morning.

\section{Experimental Technique.}

Sampling Stations.

Regular monthly samples were taken at three stations which were selected as likely to be different yet characteristic areas; in addition, samples were taken at less regular intervals at other places.

The regular stations were :-

1. Loch Striven. This loch is notably free from steamer traffic, and the adjoining land is sparsely populated. It thus represents an area remarkably free, in view of its proximity to land, from industrial or other human contamination.

2. Loch Long (Thornbank Station). This station is moderately free from land contamination, but there are habitations along the shores of the loch, and there is a certain amount of boat traffic. Terrestrial influences are thus more marked here than in Loch Striven.

3. Greenock. Here the water is estuarine in character, and highly polluted with sewage, with waste from sugar refineries and with industrial effluents generally, which are emptied into the River Clyde. This area was chosen in order to determine to what extent the true water bacteria would be outnumbered by those species present as a result of contamination. A detailed account of the Clyde Sea Area is given by Mill (19) ; a map of the area and a summary are also given by Marshall and Orr (17).

\section{Sampling Technique.}

Vertical series of samples were taken periodically at the abovementioned stations. It was necessary to employ an apparatus capable of collecting water at the desired depth without taking in water from other depths when being hauled up. The closing water-bottles generally employed in marine work are not suitable for the collecting of sea-water destined for bacteriological analysis. The following are the principal objections :-(i.) Such bottles are made of metal, and most metals have a marked bactericidal effect. This objection is not a cogent one if the sample is in the bottle for only a short time (3). (ii.) When a series of samples has to be taken with one bottle, each sample has to be siphoned into a sterile container for transport ashore, and while this operation is being carried out there is a risk of contamination. (iii.) Between the taking of successive samples it would be necessary to sterilise the bottle, 
and these water-bottles are usually so unwieldy that it is laborious to accomplish this effectively.

Several bacteriological samplers have been described, notably those by Bertel (4), Russel (21), Portier and Richard (20), Drew (8, 9), Matthews (18), Birge (6) and Sclavo-Czaplewski (14). The simplest type consists essentially of a stoppered bottle, the stopper being pulled out at the required depth. The chief disadvantage of the method is that the removal of the stopper requires a second line which is apt to foul the lowering wire. The second type consists of a glass container with a drawn-out sealed tip ; this tip can be broken by a messenger when the apparatus is at the required depth. Matthews has described a deep-sea bacteriological water-sampler of more complicated design than the foregoing.

For the work described in the following pages a comparatively simple apparatus was required, capable of use to a depth of 60 fathoms. Eventually a sampling apparatus similar to that described by Birge (6) and Wilson (24) was selected.

It consists of (i.) a glass sampling tube and (ii.) a metal tube-holder. The tube is an ordinary combustion tube $15 \mathrm{~cm} . \times 3 \mathrm{~cm}$., fitted with a one-holed rubber cork. Through this projects a glass tube bent at a right angle, having the end drawn out and sealed at about $12 \mathrm{~cm}$. from the bend. The right-angle tubes are fitted into the corks, and together with the combustion tubes sterilised by steam. These are then fitted together, due precautions being taken to avoid contamination of the parts.

The tube-holder consists of a plate-sinker A (Fig. 1), with a spring clamp B to hold the sampling tube in position. At the top of the sinker is a projecting arm at the free end of which is a small brass breaking pin C. There is also a lever arm D so placed that when the sampling tube is in position the tip of the inlet tube lies immediately above the end of the lever arm and immediately under the breaking pin. When the apparatus reaches the required depth a messenger is sent down the connecting wire to operate the lever arm; in this manner the tip of the capillary tube is broken.

The above apparatus was modified by Wilson from the sampler used by Russel (21) and was designed for limnological work in shallow waters down to 23 metres; Wilson evacuated his sampling tubes, but the author found experimentally that at a depth of 10 fathoms a tube filled with air at atmospheric pressure would take a sample whose volume would be about half that of the whole tube; at greater depths, the increased pressure caused proportionally greater filling of the tube. Most of the samples were taken at depths greater than this, and it was necessary to evacuate only those tubes destined to take surface samples.

The apparatus was sent down on a Kelvin sounding wire worked from a sounding machine recording in fathoms. 
Evacuation of the surface sampling tubes was accomplished in the following manner :- sterile glass tubing was prepared as shown in Figure 2 and attached to a sterile sampling tube. This was evacuated to a pressure
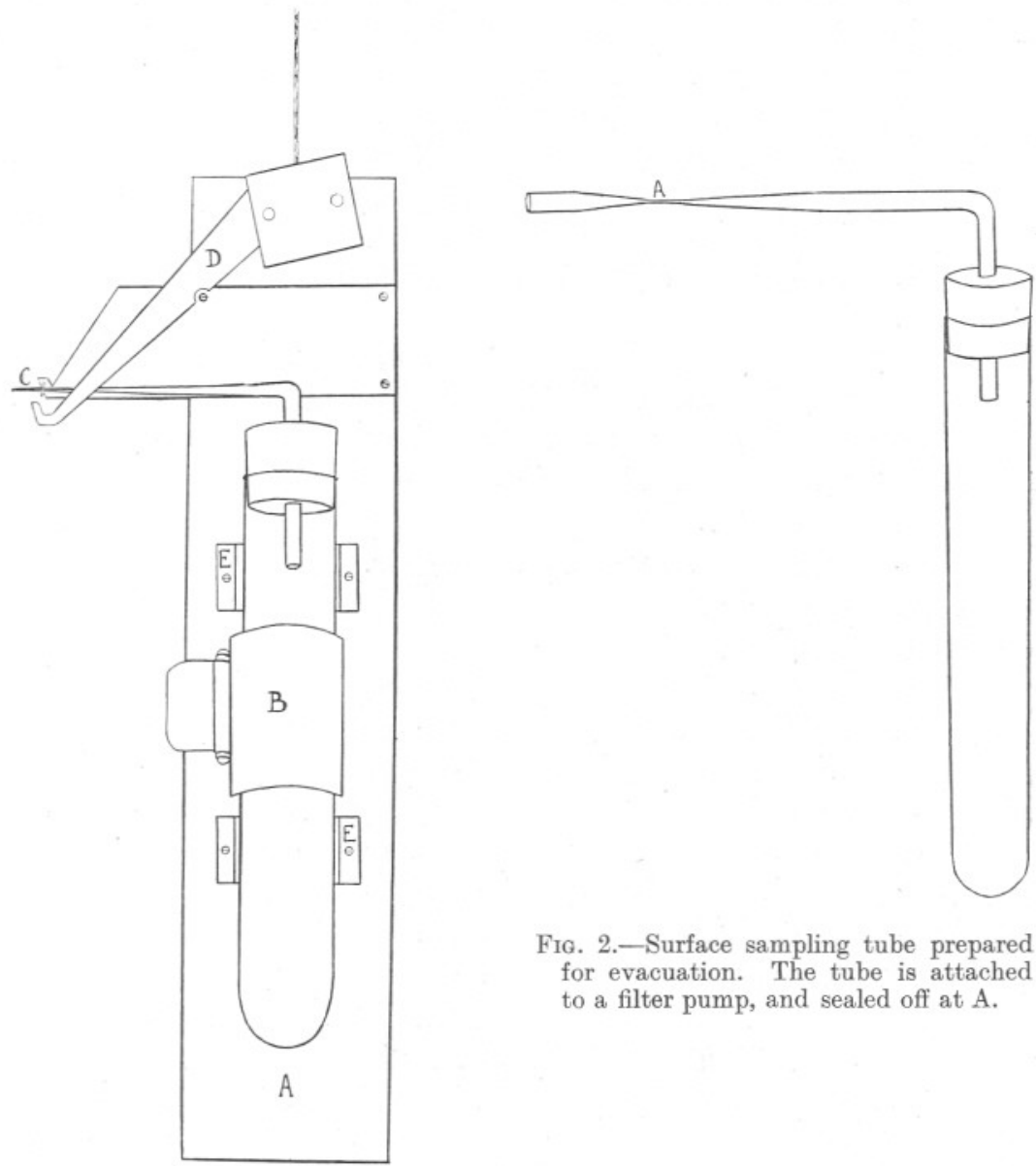

Fig. 2.-Surface sampling tube prepared for evacuation. The tube is attached to a filter pump, and sealed off at A.

Fig. 1.-Wilson's bacteriological watersampler, showing sampling tube in position and lever arm open. A, platesinker; B, spring clamp; C, breaking pin; D, lever arm; E, rubber cushion.

of $30-60 \mathrm{~mm}$. and sealed off at A. The connections at the rubber were made air-tight with paraffin wax.

The advantages of this apparatus lie chiefly in its simplicity, the extreme rapidity with which a series of samples can be taken at any one station, and the circumstance that the same tube serves both for taking the sample and for transporting it to the laboratory. The rubber cork is 
liable to be forced inwards as the sampler descends; if this occurs the tube breaks at the right-angle bend. In practice this can be avoided by selecting well-tapered corks, though for constant deep-water work it would be necessary to have the sampling tube and the inlet arm blown in one piece after the retort-shaped type used by Drew (8) for depths greater than 70 fathoms.

While the sampler is being hauled up, the tip of the tube is of course open, but there is no admixture with water from the upper layers through which it is passing, for as the apparatus is being raised the pressure in the tube is being continuously reduced and the compressed air is flowing out of the tube at the narrow orifice. An inflow of water is therefore prevented.

For the quantitative work described below, samples were taken in vertical series at intervals of 10 fathoms from the surface downwards. For transit ashore the open tips of the tubes were sealed off in the flame of a spirit lamp, and packed in sterilised cotton-wool.

\section{Transport of Samples.}

In making total counts of the bacterial content of water the following are significant factors :-

(i.) The time interval which elapses between the taking of the sample and its examination in the laboratory, because during that period the bacteria present in the sample may be actively dividing. In the course of this work, the samples at any one station were always taken at the same time of day, and dealt with in the laboratory after approximately the same time interval. In this way uniformity of treatment was ensured, and the numerical results so obtained at any one station for different dates are comparable with one another.

Time of Sampling. Time of Inoculating.

$\begin{array}{lrl}\text { Loch Striven } & 12.30 \mathrm{p} . \mathrm{m} . & 5.0 \mathrm{p} . \mathrm{m} . \\ \text { Loch Long } & 1.0 \mathrm{p} . \mathrm{m} . & 5.30 \mathrm{p} . \mathrm{m} . \\ \text { Greenock } & 4.0 \mathrm{p} . \mathrm{m} . & 6.0 \mathrm{p} . \mathrm{m} .\end{array}$

(ii.) The temperature at which the samples are kept during transport. It is advisable to inhibit bacterial reproduction by keeping the samples on ice until they are examined in the laboratory. It was found that when samples were transported in a padded box, the temperature of the water on arrival at the laboratory was not raised more than $2^{\circ} \mathrm{C}$.; the rate of multiplication of the bacteria would thus not be appreciably increased.

\section{Laboratory Technique.}

The technique adopted for routine work followed as nearly as possible the procedure recommended by the American Society of Bacteriologists 
(1) for the standard examination of water. The regular bacteriological examination of sea-water does not appear to have called for special attention in their schedule.

The following culture media were used :--

Standard Agar.

$\begin{array}{lr}\text { Tap-Water } & 1000 \mathrm{gm} . \\ \text { Lab-Lemco } & 3 \mathrm{gm} . \\ \text { Peptone (Witte's) } & 10 \mathrm{gm} . \\ \text { Agar } & 15 \mathrm{gm} . \\ \mathrm{NaCl} & 5 \mathrm{gm} .\end{array}$

The medium was prepared in the usual way, cleared with $10 \mathrm{gm}$. eggalbumen dissolved in 100 c.c. of water, and adjusted with $\mathrm{NaOH}$ to neutral, using phenolphthalein as an indicator. The agar was sterilised by autoclaving for 30 minutes at a pressure of 2 atmospheres (Giltner, 12 . p. 40).

The following modifications were tried experimentally :-

(i.) Tap water and $\mathrm{NaCl}$ were replaced by filtered sea-water.

(ii.) $\mathrm{NaCl}$ was replaced by 34 grams of evaporated sea salt.

(iii.) Tap water and Lab-Lemco were replaced by fish extract. The fish extract was prepared by slowly heating 1 kilog. of cod in 1 litre of sea-water for about 4 hours; it was then filtered and made up to 1 litre with tap water.

These media all favoured growth, but they were not found to be markedly superior to the ordinary bacteriological media, and therefore they were not used for routine quantitative work.

Standard Gelatine. This was prepared in the same manner as the foregoing, using 150 grams of gelatine per litre instead of the agar (12, p. 35).

Conredi-Drigalski Agar.

(a) Water

Agar

$\mathrm{NaCl}$

Nutrose

Peptone

Lab-Lemco

(b) Azolitmin (2.5\%)

Lactose

$\mathrm{Na}_{2} \mathrm{CO}_{3}(10 \%)$

Crystal Violet $(0.1 \mathrm{gm}$. in 100 c.c.)
2 litres.

$60 \mathrm{gm}$.

$10 \mathrm{gm}$.

$20 \mathrm{gm}$.

$20 \mathrm{gm}$.

$6 \mathrm{gm}$.

40 c.c.

30 gm. in 100 c.c. water.

4 c.c.

20 c.c.

NEW SERIES.-VOL. XVI. NO. 3. MAY, 1930. 
The agar $(a)$ is prepared in the usual way and sterilised. The ingredients $(b)$ are sterilised separately and added to the hot agar (12, p. 387).

On this medium the growth of non-intestinal organisms is inhibited. The presence of colonies is presumptive evidence of fæcal contamination; the coliform lactose-fermenting species appear as red colonies, and the typhoid-dysentery group as white or blue colonies.

McConkey Agar.

$\begin{array}{lc}\text { Water } & 500 \mathrm{c.c} . \\ \text { Peptone } & 10 \mathrm{gm} . \\ \text { Agar } & 7.5 \mathrm{gm} . \\ \text { Neutral Red (1\%) } & 1.25 \mathrm{c.c} . \\ \text { Sodium taurocholate } & 2.5 \mathrm{gm} . \\ \text { Lactose } & 5 \mathrm{gm} .\end{array}$

The lactose is added to the hot agar after filtration. This medium aliso inhibits the growth of non-intestinal species.

Litmus-lactose-bile-salt Broth.

$\begin{array}{lr}\text { Tap Water } & 1000 \mathrm{gm} . \\ \text { Sodium taurocholate } & 5 \mathrm{gm} . \\ \text { Peptone } & 20 \mathrm{gm} . \\ \text { Lactose } & 10 \mathrm{gm} . \\ \text { Azolitmin }(2 \%) & 20 \mathrm{c.c} .\end{array}$

The peptone and sodium taurocholate are boiled and the lactose and azolitmin added afterwards. Fermentation of the lactose is presumptive evidence of the presence of intestinal organisms (12, p. 382).

Of the above media, the first two were used for ordinary quantitative work, and the last three for the detection of pollution.

Plate cultures were made by adding measured volumes of the sample to the nutrient media. The inoculations were made at as low a temperature as possible, i.e. above $35^{\circ} \mathrm{C}$. for agar, and above $25^{\circ} \mathrm{C}$. for gelatine. At this temperature the medium is still liquid, and is not so hot as to kill the ordinary micro-organisms.

From each water sample the following cultures were made :-

(a) Agar : 1.0 c.c., $1 \cdot 0$ c.c. (duplicate), 0.5 c.c., $0 \cdot 1$ c.c., and a control plate, not inoculated.

(b) Gelatine : as for agar.

(c) Conradi-Drigalski agar : $1 \cdot 0$ c.e.

(d) McConkey agar : $1 \cdot 0$ c.c.

(e) Litmus-lactose-bile-salt broth : one tube culture. 
Quantitative Work. Cultures $(a)$ and $(b)$ were incubated in dark containers at room temperature. At the fifth day after inoculation the number of colonies was counted with the naked eye; after this period of incubation the number was fairly constant.

Some departures were made from the accepted routine for the bacteriological examination of water. Firstly, the incubation temperature was some six to twelve degrees lower than that usually employed. This was done for two reasons: (i.) to encourage the growth of the true water bacteria, which appear to thrive better at a temperature lower than that which favours soil bacteria; freshwater bacteria, and presumably marine bacteria also, are extremely sensitive to high temperatures both during plating and during incubation. (ii.) to discourage the growth of any organisms present which grow best at higher temperatures, as, for example, coliform bacteria. In this way the colonies which grew on the agar and the gelatine plates were representative chiefly of the true water bacteria.

A second departure from the usual routine was that the dilution method not being necessary was not employed. It had been ascertained by preliminary tests that the number of colonies obtained from an inoculum of $1 \cdot 0$ c.c. could easily be counted. In the Greenock area the total number of bacteria was very high, but this was due largely to putrefactive and intestinal organisms, and since their growth was discouraged by the low incubation temperature employed, the numbers obtained on agar and gelatine plates represent the approximate number of true water bacteria and not the total number of bacteria present.

A third point of difference from ordinary routine lay in the method of recording results. The American Society of Bacteriologists (1) recommend that, in order to avoid fictitious accuracy, the numbers obtained from bacterial counts should be approximated as under :-

1- 50 recorded as enumerated.

51- 100 recorded to the nearest 5 .

$101-250$ recorded to the nearest 10.

251- 500 recorded to the nearest 25 .

501-1000 recorded to the nearest 50 .

This recommended procedure is, however, intended for use in reports based on the evidence of one sample only for any one locality. This plan was not adopted in this work, but the actual figures obtained are given, since a number of plates was made for each sample and a number of samples was taken for each place at intervals throughout a year.

Detection of Pollution. Conradi-Drigalski and McConkey plates $(c)$ and $(d)$ and broth tube $(d)$ were incubated at $37^{\circ} \mathrm{C}$. for 24 hours. Any 
colonies which appeared by the end of that period were presumptive coliform organisms, the red colonies being of course lactose fermenters. When the numbers so obtained were compared with the gelatine and agar counts for the same sample, it was possible to estimate the proportion of high-temperature intestinal organisms to low-temperature free-living organisms. This indicated not only whether the water sampled was polluted or not, but also the degree of pollution of the sample.

\section{REsUlts.}

Loch Striven. This is the type area of natural sea-water, with minimal contamination despite its proximity to land. The numerical results of the plate cultures made from the samples taken each month are given in
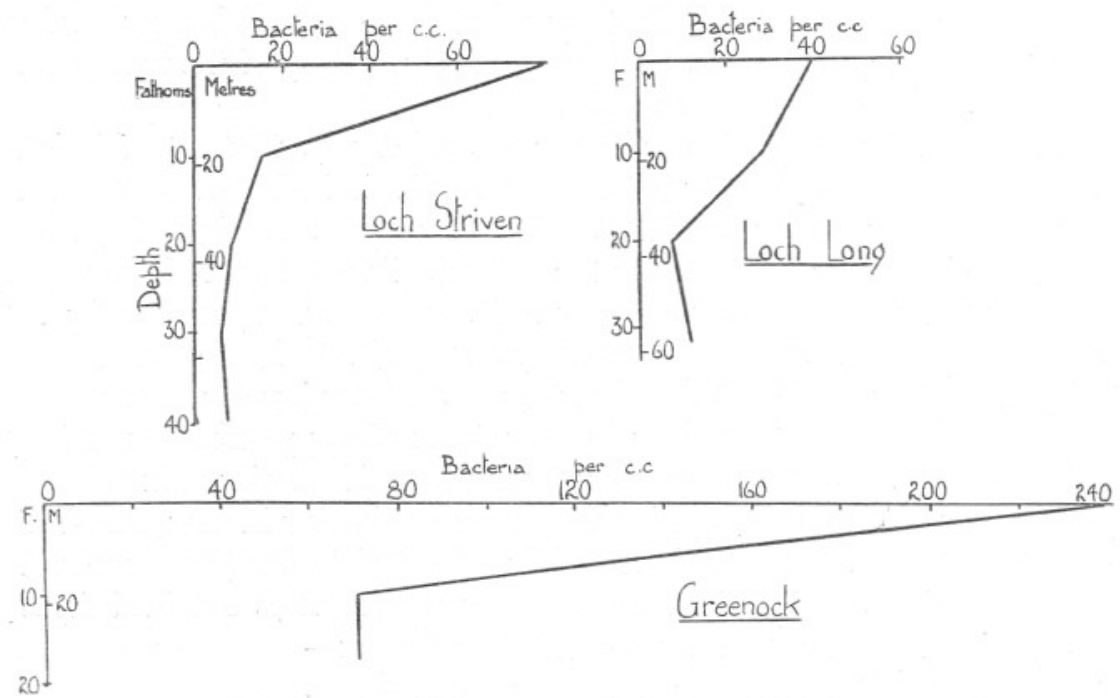

FIG. 3.-Average number of bacteria per c.c. for the year, May, 1928-April, 1929.

Table I. The average number of bacteria per c.c. is estimated for each sample from the total volume of water-sample plated out (usually $5 \cdot 2$ c.c.) ; these averages are given in the last column.

Samples were taken at the surface, and at intervals of 10 fathoms down to the bottom; the bottom sample was taken immediately above the mud, in approximately the same place, but as the sides of the loch were steep, the depth at which the bottom sample was taken varied from 37 to 40 fathoms.

The following results are noted :-

Vertical Variation. 1. The number of bacteria per c.c. is low compared with that of other stations in the Clyde Sea Area. 
2. The number of bacteria is greater at the surface than at lower levels (Fig. 3).

3. At the surface, the bacterial content of the water fluctuates much more than in deep waters, where it is more nearly constant.

4. At and below 10 fathoms, the number of micro-organisms does not exceed 30 per c.c. at any season.

5. Bottom samples show a rather lower bacterial content than the water at higher levels. This is an unusual feature, which will be discussed in the following section.

Seasonal Variation. 1. The numbers of bacteria per unit volume vary only little throughout the course of a year. Any variations outside the limits of accuracy of the experimental methods adopted appear to be erratic and therefore cannot be correlated with any factor varying seasonally. Such fluctuations may be due to external factors which operate only intermittently. This is particularly applicable to the surface waters, whose composition varies so much with conditions affecting drainage from the land $\left(\mathbf{1}^{\prime}\right)$.

2. At the surface and below, the bacterial content is relatively high in August.

Diurnal Variation. The samples just described were taken at intervals of several weeks, so they do not show short-period variations due to such factors as tide, sunshine, and perhaps diatom increases. Accordingly, samples were taken in vertical series quarterly at 3-hour intervals over a period of 24 hours. The experimental conditions differed from those under which the other periodical samples were examined. Plating was done on the boat immediately after sampling; two agar plates were made from each sample, using $1 \cdot 0$ c.c. as inoculum. Gelatine plates were not employed, as the lower solidifying point of gelatine made it unsuitable for plating work carried out on a boat. Four such 24-hour series were made. The results are given in Tables $\mathrm{II}_{\mathrm{A}}, \mathrm{IIB}_{\mathrm{B}}, \mathrm{IIC}_{\mathrm{c}}$ and IID.

Winter Series, December 19/20, 1928. The following results were observed :-

1. The general vertical distribution over the 24 hours agrees with that of the monthly samples, i.e. there is a progressive decrease in the bacterial content from the surface to the bottom and the surface samples show wider fluctuations.

2. The number of surface bacteria is unusually high: this may be correlated with the fact that the herring fishing was in progress at the time.

3. At any given depth the numbers were higher at night, with a tendency to decrease from 7 p.m. till the early hours of the morning 
(Fig. 4). With increasing depth the maximum occurs at a later hour, but this may be due to chance variations.

Spring Series, March 7/8, 1929. From Table IIв the following observations were made :-

1. The number of surface bacteria is unusually low. This may have been due to the low temperature then prevailing, and to the fact that the herring fishing had ceased some weeks earlier. These possible causes are discussed in the following section.

2. There is an increase in the number of bacteria during the night hours, the highest numbers being attained at 3 a.m. in all except the bottom samples (Fig. 5).

Summer Series, July 23/24, 1929. From Table IIc the following observations were made :-

1. In this series, the number of surface bacteria is again relatively high and fluctuates very much between the 3-hour samplings.

2. The lowest surface numbers are at noon and the highest at 5 p.m.

3. Below the surface the numbers were fairly constant, but at 10 and at 20 fathoms there were increases after midnight (Fig. 6).

Autumn Series, October 24/25, 1929. These samples confirmed the findings of the three previous series. The following conclusions were drawn (Table IID) :-

1. The number of surface bacteria fluctuates very much, but on this occasion there were relatively few organisms in the surface water.

2. At lower levels there was in general an increase in numbers during the night, so that the bacterial content tends to be highest in the early morning hours (Fig. 7).

In summing up the results of these series of bacteriological analyses spread over a period of a year, it is seen that (i.) the number of surface organisms is usually relatively high, and is much subject to short-period variations, (ii.) in deeper water layers the bacterial content is very much lower and remains almost constant throughout the year, and (iii.) during the hours of darkness the numbers tend to increase slightly.

\section{Results of Pollution Tests.}

Conradi-Drigalski agar and McConkey agar were used as routine media for the detection of pollution. Both these media inhibit, or at least retard, the growth of all but intestinal bacteria, so that the presence of colonies on a plate inoculated from a water sample is presumptive evidence of the contamination of that water. Most of such colonies will appear red and will be the lactose-fermenting $B$. coli or its congeners. This can be confirmed by a lactose-broth culture made from the same 

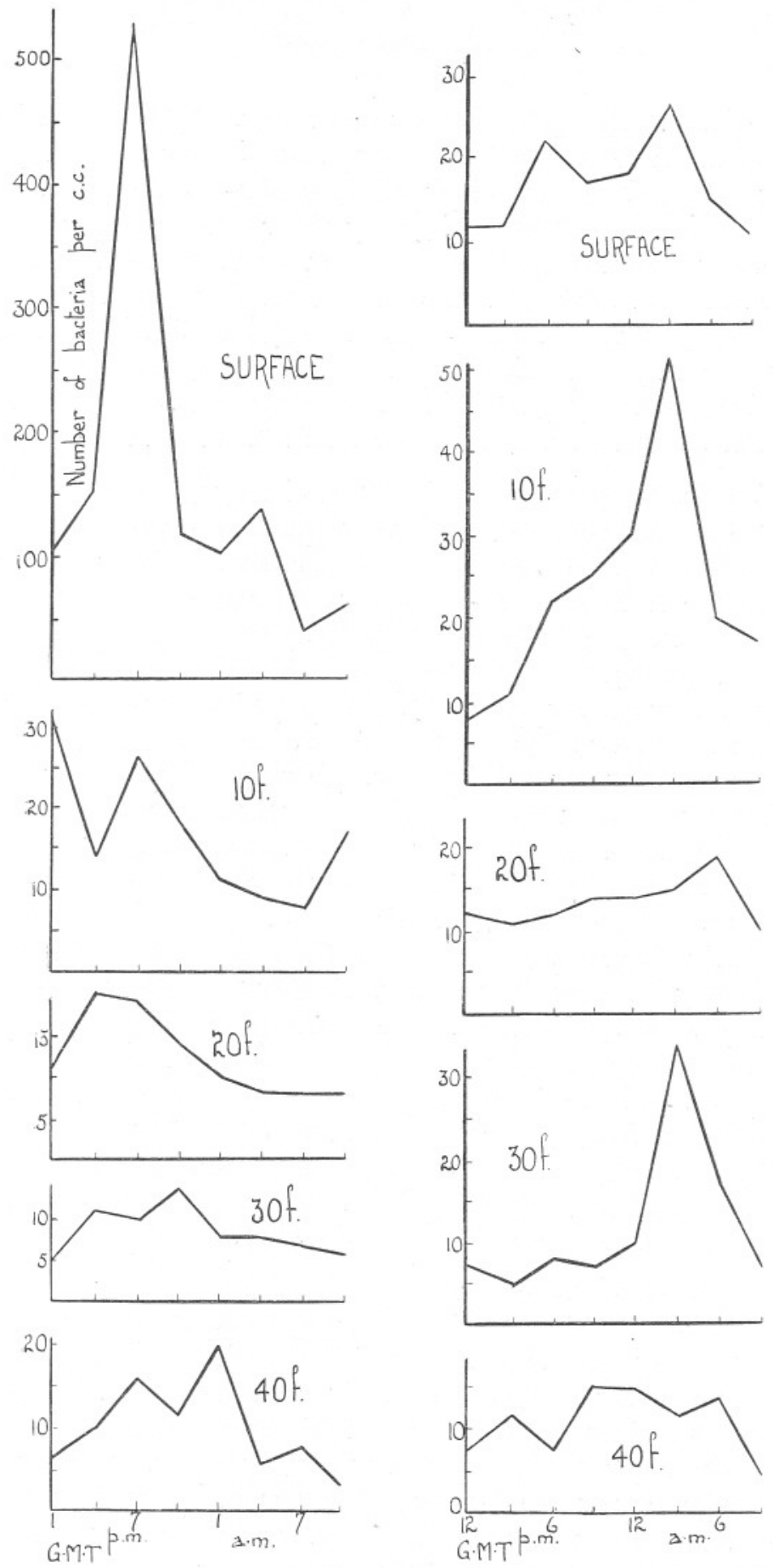

Frg. 4.-Diurnal variation in the numbers of bacteria at different depths. Samples taken 19/20.xii.29. Loch Striven.

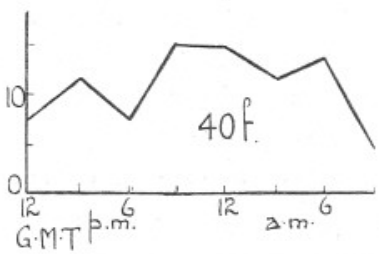

FIG. 5.-Samples taken 7/8.iii.29. Loch Striven. 
water sample. The intestinal organisms, e.g. B. typhosus, Morgan's bacillus, which do not ferment lactose, are less common in polluted water; on the above media they appear as blue-white colonies.

It was found that bacteriologically the Loch Striven waters were remarkably pure throughout the greater part of the year. During the winter months, however, when the herring fishing was in progress, the surface samples showed an increase in the total bacterial content, and this was due in part to an increase in the numbers of presumptive coliform organisms, when they formed about $20 \%$ of the total. When the herring season was over, however, the water became free from these organisms.

Loch Long. The results given in Table III show that at Loch Long the vertical distribution of bacteria is very similar to that of Loch Striven, though the bacterial content is in general higher. This is possibly to be connected with the greater accessibility of this loch to steamer traffic.

Here again there is little evidence of regular seasonal variation (Fig. 3). Table III shows that the bacterial content of the surface water varies widely and apparently erratically. The samples taken at other levels show a midsummer minimum, an autumn increase and a minimum in the months of January and February. Very few bacteria were present in the January samples; at this time the temperature was so low that the waters at the head of the adjoining branch, Loch Goil, were frozen. This seems to bear out the opinion generally held that water bacteria are specially sensitive to changes in temperature.

Normally there are more bacteria at the surface than at other levels; there is only one exception, namely, the May series of samples taken in Loch Long. Here a much higher bacterial content is found at 10 fathoms. For this there does not appear to be a suitable explanation, unless we have regard to the fact that the number of presumptive coliform organisms obtained on McConkey plates on that date was specially high and that 3 out of 4 lactose-broth cultures produced gas. This points to some special circumstances causing localised subsurface contamination of the water at the spot where the samples were taken.

Greenock. In this area the samples were taken at the deepest part of the river channel off Greenock, where the water is much polluted with sewage and with industrial effluents. The effect of such pollution will of course be more marked near the shore-line. Between the coast and mid-channel there is a certain amount of self-purification of the water ; nevertheless, the bacterial content of the open water is affected. The number of organisms per c.c. is considerably higher than in the lochs (see Table IV and Fig. 3) ; further, the number of colonies on McConkey plates is many times more than the number on gelatine and agar plates, so that it is not possible to estimate the number of coliforms without dilution of the 

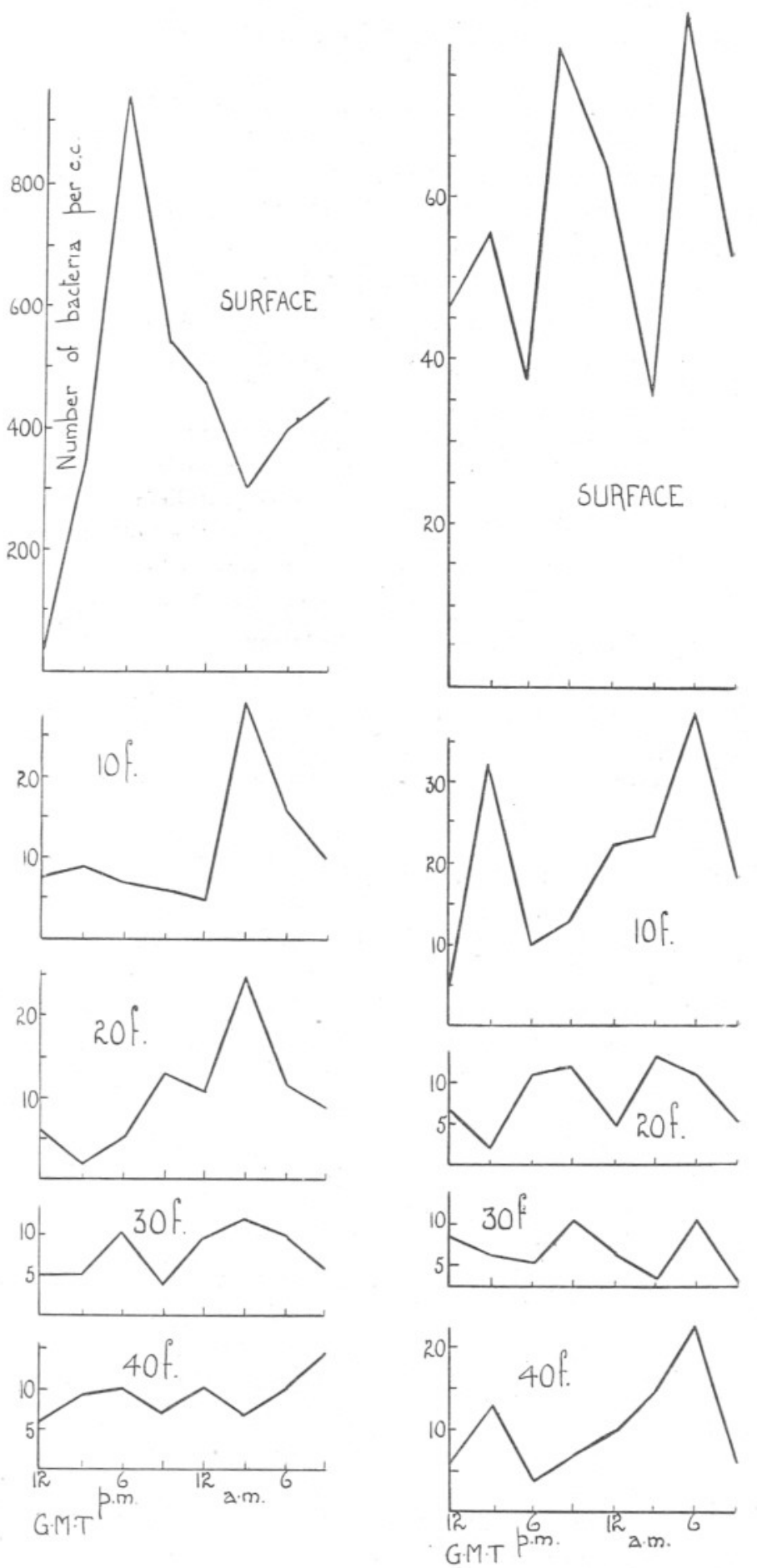

Fig. 6.-Diurnal variation in the numbers of bacteria at different depths. Samples taken

FIg. 7.-Samples taken 24/25.x.29. Loch Striven. 23/24.vii.29. Loch Striven. 
sample before plating. In this area then a high proportion of the constituent organisms are of the intestinal type.

The surface samples again showed by far the highest numbers; at 10 fathoms it was found always that there were fewer organisms; at the bottom, however, there was an increase. In none of these was any regular seasonal quantitative variation found.

Cumbrae Deep. At the above-mentioned stations samples could not be obtained at great depths, the deepest being 40 fathoms in Loch Striven. At Cumbrae Deep, however, there is a depth of 62 fathoms. The results from one series of samples (Table V) show that the vertical distribution is similar to those of the lochs, namely, that the surface waters have a relatively higher bacterial content, that the numbers decrease with increasing depth and that they increase again near the bottom.

It is interesting to note that the number of bacteria here is higher than it is in the lochs, but Cumbrae Deep is not typical of the Clyde Sea Area, since it is used as a dumping-ground for the Glasgow sewage treated by the activated sludge process at the Shieldhall Sewage Disposal Works. Buchanan states that such activated sludge, like crude sewage, has a bacterial flora of largely intestinal species (see 13, p. 2); this sludge therefore appears to affect the bacterial content of the sea-water into which it is discharged.

Millport. The foregoing samples were taken in open water. For purposes of comparison, samples were taken $(a)$ in the intertidal zone and $(b)$ in a high-water rock pool, and the bacterial content investigated. From the results given in Tables VI and VII it is seen that the numbers of bacteria are very much higher than in the open water-a fact to be correlated with the congestion of other living organisms in the strip of water bordering the land.

\section{Factors Affecting Distribution of Bacteria.}

The foregoing work deals only with the free-living bacteria; these may be differentiated by their mode of nutrition into prototrophic and metatrophic species. It is not yet definitely established to what extent the prototrophic forms, as for example, the nitrogen-fixing bacteria, are found free-living in the sea. Ordinary marine conditions are not always favourable for their growth, so their existence is problematic. Experimental proof of their activity is available, but much of the work done on the subject is contradictory.

The majority of free-living bacteria are metatrophic, deriving their organised food-stuffs directly or indirectly from other organisms. In the sea two classes may be conveniently distinguished :- 
(i.) The saprophytes living on and attached to particles of an organic nature, such as decaying seaweed, dead plankton and terrigenous detritus. This group will include the putrefactive bacteria; they will be common where suspended matter is common and will be particularly abundant where such particles will accumulate, as for instance at the sea-bottom.

(ii.) The true planktonic bacteria, which have a simple metabolic cycle, and whose source of food is the dissolved organic material - aminoacids, proteins, and carbohydrates,-present in the sea, particularly in the surface waters near the coast-line.

(a) Sunlight. Among the physical factors affecting bacteria, sunlight is well-known to have a deleterious action on the growth of microorganisms. This is due to the bactericidal action of ultra-violet light, and is to be distinguished from the ordinary retarding effect of light on growth. If the insolation is sufficiently intense, it would be expected that this effect would be most marked at the surface. The foregoing results for the Clyde Sea Area, however, show a greater number of bacteria at the surface, even when the samples were taken on sunny days, so that the bactericidal effect of light was apparently negligible. Schmidt-Neilsen (23), on the other hand, records finding at Dröbak 26 bacteria per c.c. at the surface and 420 per c.c. at a depth of 25 metres, and states that this progressive increase with depth is possibly due to the influence of sunlight. Similarly Bertel (5) found that off the coast of Monaco the numbers increased with depth. From two series of samples he found that the numbers increased from 1 per c.c. at the surface, $(a)$ to 30 at a depth of 200 metres, $(b)$ to 36 at a depth of 400 metres; these results were obtained during the months of May and June, when insolation is intense.

In the same way, the bactericidal effect of sunlight would be expected to be more marked during the summer months, and, if it were the limiting factor, the numbers of bacteria would be lower in the summer than in the winter months. For the Clyde Sea Area, the bacterial content of the water on the whole is lower in the period from June to August, but it is not possible at this stage to correlate such seasonal variations with definite variations in the intensity of light. There do not appear to be other seasonal records with which these results may be compared.

The diurnal variation in the bacterial content may be due in part to the effect of sunlight. Tables IIA, B, C, and D show that in general there is an increase during the hours of darkness. This confirms the findings of Fischer (10), that more bacteria are to be found at sunrise than in the afternoon. Bertel (5) also states that there is a night-time bacterial increase which persists even to the early hours of the morning. He bases his conclusions, however, on the evidence of three series of samples taken 
on different dates, so that it is possible that other factors came into play during the intervals. From his experimental work Bertel deduces that the night-time is more favourable for reproduction by bacteria; but the fact that bacteria are more numerous at night does not prove that they necessarily reproduce more rapidly at night, since other factors such as the vertical mixing of water may cause movement of particles supporting bacteria from one water level to another.

(b) Temperature. An increase of temperature within certain limits favours the growth of micro-organisms in general. Sudden and marked changes in temperature may, however, have an unfavourable effect on bacteria, particularly on those species which do not form spores and which have not a highly resistant cell-membrane. Water bacteria are in general small non-sporing bacilli, notoriously sensitive to sudden changes in temperature (2).

Ordinarily, in the Clyde Sea Area the range of temperature variation is not sufficiently wide to show its effect on the bacterial content of seawater. An examination of the results of the January samples taken in Loch Long shows the number to be very low ; these samples were taken during an extremely cold spell when the head waters of the adjoining loch were frozen.

(c) Movements of Wuter. In a still body of water it would be reasonable to expect a greater number of micro-organisms at the surface and at the bottom than in the intervening layers. However, any movements which cause vertical mixing from one layer to another may cause shortperiod variations in the bacterial content of the water at any depth. In view of this, it is remarkable that for the Clyde Sea Area the vertical progressive diminution in the number of bacteria is so constant.

Near land masses, especially off the steep western coast of Scotland, there is a tendency for vertical upwelling of water from the bottom and a surface flow away from the land. Foodstuffs are thus brought up to the surface, and become available for aerobic marine bacteria. At the same time, land drainage contributes its quota of detritus and soluble organic compounds, the less dense fresh water tending at first to distribute itself over the surface $\left(\mathbf{1}^{\mathrm{r}}\right)$. Thus the surface waters appear to be best furnished with foodstuffs for the support of a more numerous bacterial population than is found at lower water levels. Almost all the samples taken illustrate this.

Tidal movements, similarly, may affect the bacterial content of the water. The results of the German Plankton Expedition (10) show that the number is higher during the ebb than during the flood tide. This influence is more marked when there is a slightly shelving coast-line with a comparatively broad intertidal zone which supports much plant and animal life, the number of bacteria being correspondingly high. In 
the lochs investigated, however, the steeply sloping sides afforded only a narrow intertidal zone, and the tidal variations do not appear to have much effect on the bacterial content of the water. This is best shown in Tables $\mathrm{II}_{\mathrm{A}}, \mathrm{B}, \mathrm{C}$ and $\mathrm{D}$, where samples were taken at 3-hour intervals over periods of 24 hours at various seasons of the year.

(d) Sedimentation of Organic Particles. Attention has already been drawn to the fact that the saprophytic bacteria are not truly planktonic, but are attached to suspended organic particles of various origins. Any factor which determines the distribution of these particles will affect also the number of saprophytic bacteria. In water where there are no currents and no vertical mixing, it would be reasonable to expect at the surface an accumulation of such organic matter as has lower density than sea-water, with a corresponding accumulation of bacterial saprophytes. Similarly, the deposits at the bottom induce a high number of bacteria. In the intervening layers, however, through which suspended matter, as for example, the "plankton rain," tends to sink slowly, the number of bacteria also decreases progressively with depth.

Almost all the vertical series of samples taken in the Clyde Sea Area show this, viz., a relatively high bacterial content at the surface, with a gradual decrease till the bottom is reached, when the numbers again rise. Probably the increase at the bottom is due to the proximity of the mud which exists at all the stations. Some work now in progress has shown that the number of bacteria in the mud itself far exceeds that of the water immediately above it.

(e) Biological Factors. Since most water bacteria are heterotrophic, they will enter into competition for foodstuffs with the simpler animal forms, and will in turn be preyed upon by protozoa. It is well known that in the soil the numbers of protozoa and bacteria bear a numerical relationship to one another, namely, that when one group is abundant, the other is scarce and vice versa. It is highly probable that a similar state of affairs exists in the sea, though experimental evidence is lacking. as yet.

After a period of great activity in the development of any group of organisms, there will be a glut of dead organisms and bacteria may thereafter multiply very rapidly. After the spring diatom increase in 1929, the bacterial content of the water was high, especially at the surface. There was a comparable increase during the autumn of 1928, when the herring season was in progress in Loch Striven, but not at the other stations sampled. In Loch Striven there was a great increase in the numbers of bacteria at the surface, with no corresponding increase at the other stations.

The following table shows the average number of bacteria at the surface in Loch Striven, compared with the herring catches for the season. The 
latter figures are available through the courtesy of the Fishery Board for Scotland.

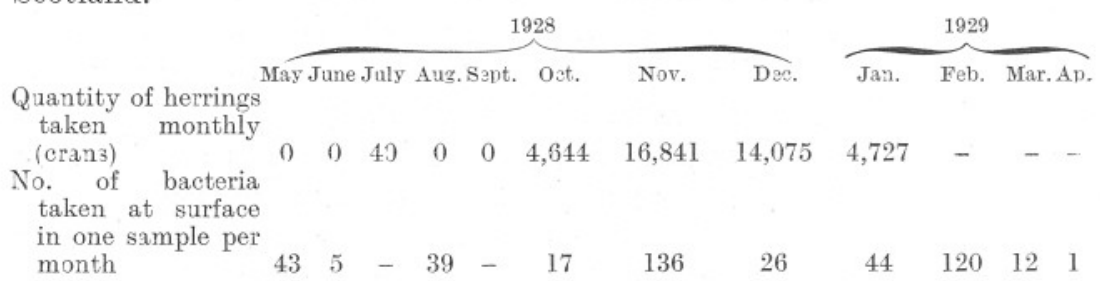

Thus it appears that the surface maximum in November coincides with the maximum herring catch ; this is followed by a decrease in numbers during December, and a second increase in February.

The writer wishes to make acknowledgments to the Scottish Marine Biological Association for permitting the frequent use of their boat, the Nautilus; to Mr. Elmhirst, the Superintendent of their Laboratory at Millport, for readily affording facilities for work there; to Professor D. Ellis and to Dr. J. A. Cranston of the Royal Technical College, Glasgow, for much helpful criticism and advice; and to Mr. R. J. Nairn for frequently deputising for the writer in the collecting of samples.

\section{SUMMARY.}

1. A bacteriological survey of the Clyde Sea Area has been made over a period of a year. Water samples have been taken monthly at three stations, and also less frequently at other places. A uniform routine technique has been adopted for studying their bacterial content.

2. Vertical Variation. The surface waters were found to have the highest bacterial content. With increased depth until near the bottom, there was a progressive decrease in numbers. At the bottom there was usually a slight increase.

3. Seasonal Variation. Throughout the year the numbers were found to be remarkably constant for all layers except the surface, with only slight evidence of rhythmic seasonal variation. At the surface, the bacterial content fluctuated widely, apparently in relation to factors which are not seasonal but irregular.

4. Diurnal Variation. At the surface the bacterial content is irregular throughout the day; at lower levels, there is a slight increase during the hours of darkness, the maximum occurring in the evening hours in December, and at 3-6 a.m. in March, July and October.

5. Purity of the Water. The waters of both Loch Striven and Loch Long were found to be remarkably free from pollution. In Cumbrae 
Deep, however, and in the estuary off Greenock, the numbers of bacteria were high, and a large proportion of these were found to be presumptive coliform organisms.

\section{LITERATURE.}

1. American Public Health Association. Standard Methods for the Examination of Water and Sewage. New York, 1923.

2. Bergey, H. A Manual of Determinative Bacteriology. Baltimore, 1923.

3. Berkeley, C. A Study of Marine Bacteria. Trans. Roy. Soc. Canada, XII, 3rd series, 1919.

4. Bertel, R. Ein einfacher Apparat zur Wasserentnahme aus beliebigen Meerestiefen für bakteriologische Untersuchungen Biol..Centralbl., XXXI, 1911.

5. — - Sur la distribution quantitative des Bactéries planctoniques des côtes de Monaco. Bull. de l'Inst. Ocean. Monaco, No. 224, 1912 .

6. Birge, E. A second report on limnological apparatus. Trans. Wisconsin Acad. Sci., XX, 1922.

7. Bohart, R. M. Bibliography of Marine Bacteria. Publ. Puget Sound Biol. Stat., Vol. V, p. 309, 1928.

8. Drew, G. H. Preliminary investigations on the marine denitrifying bacteria. Year Book, No. 10, Carnegie Inst., Washington, 1911.

9. — - Investigations on marine bacteria at Andros Island, Bahamas. Ibid., No. 11, 1912.

10. Fischer, B. Die bakterien des Meeres. Ergebnisse Plankton Expedition, Bd. IV, 1894.

11. DE Giaxa. Verhalten pathogener Mikro-organismen im Meerwasser. Zeitschr. f. Hygiene, VI, 1889.

12. Giltner, W. Laboratory Manual in General Microbiology. New York, 3rd edition, 1926.

13. Harris, F. W., Cockburn, T., and Anderson, T. Biological and physical properties of activated sludge. Corporation of Glasgow, Sewage Purification Dept., 1926.

14. Janke, A. u. Zikes, H. Arbeitsmethoden der Mikrobiologie, Dresden, 1928.

15. Johnstone, J. Conditions of Life in the Sea. Camb. Univ. Press.

16. Letrs. Report of the Royal Commission on Sewage Disposal, No. 3, Vol. II, 1903. 
17. Marshali, S. M., and Orr, A. P. The relation of the Plankton to some chemical and physical factors in the Clyde Sea Area. Journ. Mar. Biol. Assoc., N.S., XIV, 1927.

18. Matthews, D. A deep-sea bacteriological water-bottle. Journ. Mar. Biol. Assoc., N.S., IX, 1911.

19. Mrlu, H. R. The Clyde Sea Area. Trans. Roy. Soc. Edin., XXXVIXXXVIII, 1891.

20. Portier et Richards. Sur une methode de prélèvement de l'eau de mer destinée aux études bactériologiques. Bull. de l'Inst. Oceanog. Monaco, No. 97, 1907.

21. Russer, H. Untersuchungen uber in Golf von Neapel lebende Bakterien. Zeitschr. f. Hyg., XI, 1892.

22. - - The bacterial flora of the Atlantic Ocean. Bot. Gaz., XVIII, 1903.

23. Sсhмidt-Nielsen, S. Beitrag zur Biologie der marinen Bakterien. Biol. Centralbl., XXI, 1901.

24. Wilson, F. Description of an apparatus for obtaining samples of water at different depths for bacteriological analysis. Journ. Bacteriol., V, 1920.

\section{TABLE I.}

\section{LOCH StRiven.}

No. of bacteria present, determined by colony counts of plate cultures incubated 5 days at room temperature.

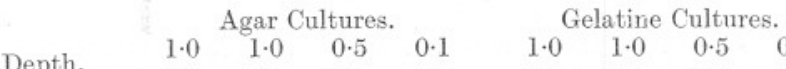

$18 / 5 / 28$

Surface

10 fathoms

20 fathoms

30 fathoms

Bottom

c.c. c.c. c.c. c.e.

$\begin{array}{llll}1 \cdot 0 & 1.0 & 0 \cdot 5 & 0 \cdot 1 \\ \text { c.c. } & \text { c.c. } & \text { c.c. } & \text { c.c. }\end{array}$

Total. Average

$15 / 6 / 28$

Surface

10 fathoms

20 fathoms

30 fathoms

Bottom

$\begin{array}{rrrr}28 & 34 & 31 & 36 \\ 8 & 47 & 1 \\ 4 & 4 & 0 \\ 6 & 2 & 0 \\ 1 & 3 & 1\end{array}$

$24 / 8 / 28$

Surface

10 fathoms

20 fathoms

30 fathoms

Bottom

36
1
0
1
0

$\begin{array}{rrrrrr}26 & - & - & - & 155 & 43 \\ 17 & - & - & - & 74 & 20 \\ 3 & - & - & - & 11 & 3 \\ 10 & - & - & - & 19 & 5 \\ 2 & - & - & - & 7 & 2\end{array}$

8
5
1
0
2

$\begin{array}{lll}3 & 0 & - \\ 3 & 6 & - \\ 2 & 0 & - \\ 0 & 0 & - \\ 2 & 2 & -\end{array}$

$\begin{array}{rr}2 & 11 \\ 10 & 13 \\ 4 & 8 \\ 6 & 7 \\ 13 & 11\end{array}$

$\begin{array}{ll}- & - \\ 6 & - \\ 6 & - \\ 5 & - \\ 3 & -\end{array}$

$\begin{array}{rrrr}43 & 30 & 28 & 1 \\ 31 & 43 & 1 & \\ 9 & 9 & 6 & \\ 15 & 21 & 18 & \\ 20 & 16 & 4 & \end{array}$

$\begin{array}{rrr}16 & 36 & 31 \\ 4 & 1 & 5 \\ 1 & 9 & 11 \\ 0 & 6 & 12 \\ 4 & 19 & 22\end{array}$

$\begin{array}{rr}7 & 13 \\ 4 & 5 \\ 1 & 5 \\ 11 & 4 \\ 29 & 7\end{array}$


TABLE I (continued).

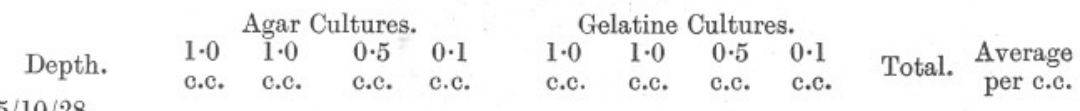
$5 / 10 / 28$

Surface

10 fathoms

20 fathoms

30 fathoms

Bottom

$\begin{array}{rrrr}15 & 24 & 2 & 0 \\ 4 & 6 & 5 & 0 \\ 9 & 8 & - & - \\ 0 & 0 & 2 & 0 \\ 0 & 1 & 0 & 2\end{array}$

$\begin{array}{rrrrrr}21 & 17 & 7 & 1 & 87 & 17 \\ 7 & 9 & 2 & 0 & 33 & 6 \\ 3 & 2 & - & - & 22 & 5 \\ 2 & 0 & 0 & 0 & 4 & 1 \\ 2 & 3 & 1 & 0 & 9 & 2\end{array}$

$2 / 11 / 28$

Surface

10 fathoms

20 fathoms

30 fathoms

Bottom

$\begin{array}{rrrr}73 & 118 & 63 & 23 \\ 9 & 18 & 6 & 1 \\ 1 & 8 & 3 & 0 \\ 6 & 2 & 1 & 1 \\ 3 & 8 & 5 & 0\end{array}$

$\begin{array}{rrrrrr}113 & 185 & 89 & 47 & 711 & 136 \\ 11 & 5 & 3 & 1 & 54 & 10 \\ 4 & 4 & 0 & 0 & 20 & 4 \\ 3 & 3 & 0 & 0 & 16 & 3 \\ 4 & 4 & 2 & 0 & 26 & 5\end{array}$

$1 / 12 / 28$

Surface

10 fathoms

20 fathoms

30 fathoms

$\begin{array}{rrrr}27 & 29 & 5 & 0 \\ 11 & 1 & 3 & 0 \\ 3 & 8 & 1 & 0 \\ 2 & 2 & 0 & 0 \\ 4 & 7 & 2 & 0\end{array}$

$\begin{array}{rrr}33 & 27 & 12 \\ 15 & 12 & 5 \\ 3 & 1 & 1 \\ 0 & 3 & 0 \\ 0 & 1 & 4\end{array}$

134

26

Bottom

$18 / 1 / 29$

Surface

10 fathoms

20 fathoms

30 fathoms

Bottom

$15 / 2 / 29$

Surface

10 fathoms

20 fathoms

30 fathoms

Bottom

$\begin{array}{rrrr}17 & 21 & 4 & 2 \\ 2 & 8 & 4 & 1 \\ 3 & 5 & 3 & 0 \\ 6 & 6 & 7 & 0 \\ 7 & 6 & 1 & 3\end{array}$

$\begin{array}{rrrrrr}90 & 81 & 12 & 1 & 228 & 44 \\ 10 & 13 & 7 & 0 & 45 & 9 \\ 2 & 7 & 1 & 1 & 22 & 4 \\ 0 & 7 & 0 & 0 & 26 & 5 \\ 2 & 5 & 1 & 0 & 25 & 5\end{array}$

$7 / 3 / 29$

Surface

10 fathoms

$117 \quad 159 \quad 22$

$\begin{array}{rrrr}40 & 42 & 20 & 15 \\ 12 & 15 & 8 & 2 \\ 8 & 7 & 5 & 3 \\ 5 & 9 & 1 & 1\end{array}$

20 fathoms

30 fathoms

Bottom

$12 / 4 / 29$

Surface

10 fathoms

20 fathoms

30 fathoms

Bottom

\begin{tabular}{|c|c|c|c|}
\hline 24 & 1 & - & - \\
\hline 10 & 7 & - & - \\
\hline 12 & 13 & - & - \\
\hline 7 & 7 & - & - \\
\hline 7 & 10 & - & - \\
\hline 0 & 1 & 0 & 0 \\
\hline 1 & 0 & 1 & 0 \\
\hline 3 & - & 2 & 0 \\
\hline 1 & 1 & 0 & 0 \\
\hline 4 & 4 & 2 & 2 \\
\hline
\end{tabular}

$\begin{array}{rrrrrr}109 & 161 & 41 & 5 & 629 & 120 \\ 29 & 9 & 6 & 4 & 153 & 29 \\ 0 & 15 & 13 & 11 & 76 & 15 \\ 6 & 11 & 2 & 0 & 42 & 8 \\ 10 & 3 & 3 & 0 & 32 & 6\end{array}$

Summary of Tables I and II. Loch Striven.

Total No. of

$\begin{array}{lcc}\text { Depth. } & \text { bacteria counted. } & \text { Average per c.c. } \\ \text { Surface } & 4565 & 80 \\ 10 \text { fathoms } & 825 & 15 \\ 20 \text { fathoms } & 433 & 8 \\ 30 \text { fathoms } & 361 & 7 \\ \text { Bottom } & 417 & 8\end{array}$

NEW SERIES.-VOL. XVI. NO. 3. MAY, 1930. 


\section{TABLE IIA.}

\section{Loch Striven.}

No. of bacteria present, determined by colony counts of plate cultures incubated 5 days at room temperature.

Winter Series, 19/12/28-20/12/28.

$\begin{array}{ccccccccc}\text { Depth. } & \text { 1 p.m. } & 4 \text { p.m. } & 7 \text { p.m. } & 10 \text { p.m. } & 1 \text { a.m. } & 4 \text { a.m. } & 7 \text { a.m. } & 10 \text { a.m. } \\ \text { Surface } & 79 & 131 & 493 & 123 & 106 & 97 & 45 & 53 \\ \text { (Average) } & 123 & 172 & 560 & 112 & 103 & 181 & 38 & 75 \\ \text { 10 fathoms } & 101 & 151 & 526 & 117 & 104 & 139 & 41 & 64 \\ & 43 & 1 & 23 & 19 & 9 & 10 & 8 & 19 \\ \text { (Average) } & 18 & 27 & 29 & 18 & 13 & 9 & 9 & 16 \\ & 30 & 14 & 26 & 18 & 11 & 9 & 8 & 17 \\ 20 \text { fathoms } & 13 & 19 & 17 & 11 & 12 & 4 & 9 & 8 \\ \text { (Average) } & 10 & 22 & 21 & 18 & 9 & 12 & 7 & - \\ & 11 & 20 & 19 & 14 & 10 & 8 & 8 & 8 \\ 30 \text { fathoms } & 9 & 13 & 12 & 14 & 11 & 6 & 2 & 2 \\ & 1 & 10 & 9 & 14 & 6 & 11 & 12 & 10 \\ \text { (Average) } & 5 & 11 & 10 & 14 & 8 & 8 & 7 & 6 \\ \text { Bottom } & 9 & 3 & 15 & 13 & - & 5 & 8 & 4 \\ & 3 & 18 & 18 & 11 & 20 & 8 & 8 & 2 \\ \text { (Average) } & 6 & 10 & 16 & 12 & 20 & 6 & 8 & 3\end{array}$

Table IIв.

Loch Striven.

Spring Series, $7 / 3 / 29-8 / 3 / 29$.

Depth. $\quad$ Noon. 3 p.m. 6 p.m. 9 p.m. Midnt. 3 a.m. 6 a.m. 9 a.m.

$\begin{array}{crrrrrrrr}\text { Surface } & 24 & 14 & 24 & 18 & 12 & 22 & 14 & 7 \\ \text { (Average) } & 1 & 10 & 21 & 17 & 26 & 29 & 17 & 16 \\ & 12 & 12 & 22 & 17 & 18 & 26 & 15 & 11 \\ \text { 10 fathoms } & 10 & 20 & 11 & 22 & 29 & 45 & 22 & 23 \\ & 7 & 3 & 33 & 28 & 31 & 57 & 19 & 12 \\ \text { (Average) } & 8 & 11 & 22 & 25 & 30 & 51 & 20 & 17 \\ 20 \text { fathoms } & 12 & 12 & 11 & 13 & 16 & 10 & 17 & 12 \\ \text { (Average) } & 13 & 11 & 13 & 15 & 12 & 20 & 22 & 9 \\ & 12 & 11 & 12 & 14 & 14 & 15 & 19 & 10 \\ 30 \text { fathoms } & 7 & 3 & 10 & 4 & 9 & 33 & 17 & 6 \\ & 7 & 7 & 6 & 11 & 11 & 35 & 17 & 9 \\ \text { (Average) } & 7 & 5 & 8 & 7 & 10 & 34 & 17 & 7 \\ \text { Bottom } & 7 & 9 & 7 & 15 & 21 & 14 & 11 & 4 \\ \text { (Average) } & 10 & 15 & 9 & 15 & 10 & 9 & 18 & 6 \\ & 8 & 12 & 8 & 15 & 15 & 12 & 14 & 5\end{array}$




\section{TABLE IIc.}

\section{LOCH Striven.}

Summer Series, 23/7/29-24/7/29.

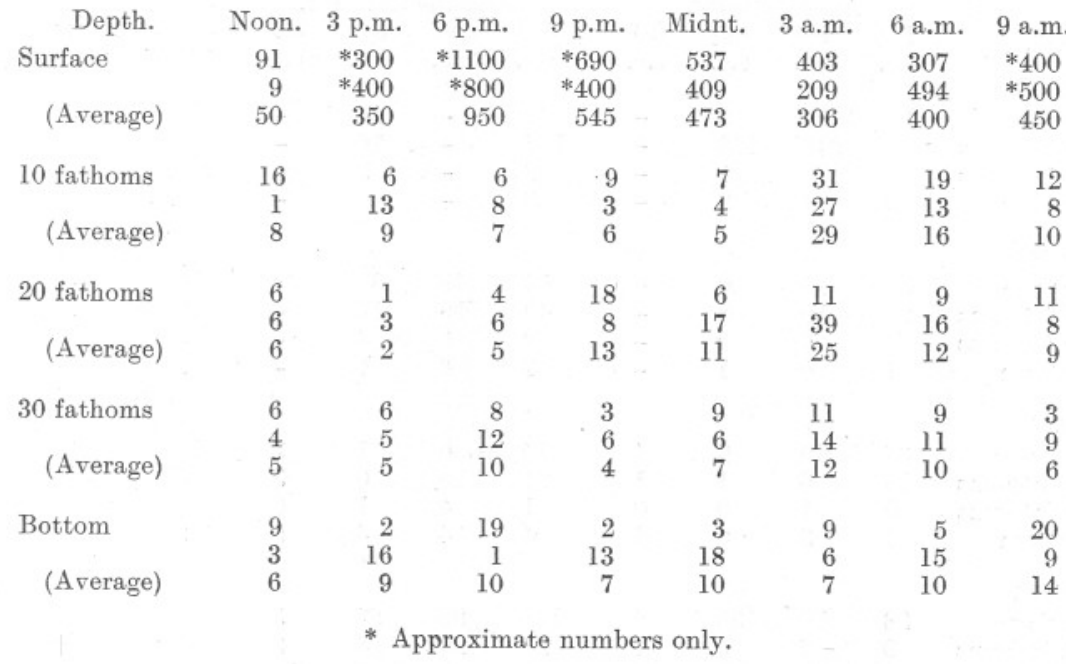

\section{TABLE IID.}

\section{Loch Striven.}

Autumn Series, 24/10/29-25/10/29.

Depth. $\quad$ Noon. 3 p.m. 6 p.m. 9 p.m. Midnt. 3 a.m. 6 a.m. 9 a.m. Surface

$\begin{array}{rrrrrrrr}41 & 59 & 41 & 66 & 49 & 32 & 101 & 61 \\ 53 & 54 & 35 & 91 & 79 & 41 & 63 & 45 \\ 47 & 56 & 38 & 78 & 64 & 36 & 82 & 53\end{array}$

$\begin{array}{rrrrrrrrr}10 \text { fathoms } & 6 & 36 & 7 & 18 & 21 & 24 & 35 & 8 \\ & 4 & 29 & 13 & 9 & 23 & 22 & 42 & 29\end{array}$

$\begin{array}{lllllllll}\text { (Average) } & 5 & 32 & 10 & 13 & 22 & 23 & 38 & 29\end{array}$

$\begin{array}{rrrrrrrrr}20 \text { fathoms } & 6 & 0 & 14 & 15 & 6 & 14 & 7 & 7 \\ \text { (Average) } & 3 & 4 & 9 & 9 & 4 & 13 & 16 & 3 \\ & 4 & 2 & 11 & 12 & 5 & 13 & 11 & 5\end{array}$

$\begin{array}{crrrrrrrr}30 \text { fathoms } & 5 & 4 & 4 & 8 & 5 & 2 & 10 & 1 \\ \text { (Average) } & 8 & 5 & 3 & 8 & 4 & 0 & 6 & 1 \\ & 6 & 4 & 3 & 8 & 4 & 1 & 8 & 1 \\ \text { Bottom } & 7 & 15 & 4 & 11 & 8 & 11 & 12 & 12 \\ \text { (Average) } & 5 & 11 & 5 & 4 & 12 & 20 & 34 & 1 \\ & 6 & 13 & 4 & 7 & 10 & 15 & 23 & 6\end{array}$




\section{TABLE III.}

\section{LOCH LONG.}

No. of bacteria present, determined by colony counts of plate cultures incubated 5 days at room temperature.

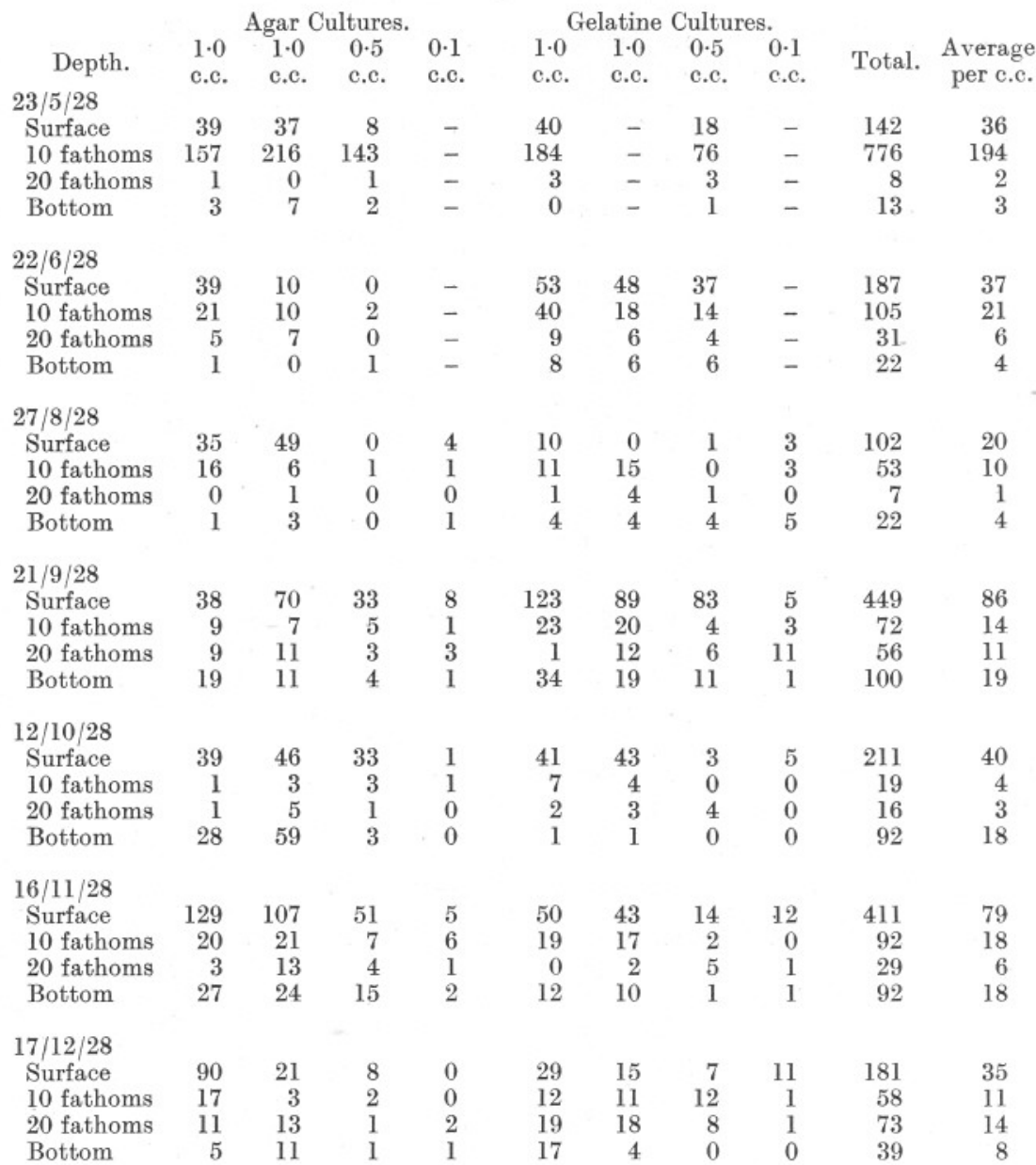

25/1/29

Surface

10 fathoms

20 fathoms

Bottom

3
1
3
6

$\begin{array}{lll}3 & 0 & 0 \\ 0 & 1 & 0 \\ 2 & 0 & 0 \\ 2 & 8 & 1\end{array}$

$22 / 2 / 29$

Surface

10 fathoms

$\begin{array}{rr}81 & 32 \\ 7 & 2 \\ 13 & 12 \\ 17 & 24\end{array}$

$\begin{array}{rr}41 & 30 \\ 0 & 0 \\ 2 & 6 \\ 4 & 1\end{array}$

$\begin{array}{rrr}33 & 30 & 3 \\ 1 & 0 & 0 \\ 2 & 9 & 0 \\ 23 & 19 & 19\end{array}$

$\begin{array}{rr}4 & 254 \\ 0 & 10 \\ 0 & 44 \\ 0 & 89\end{array}$

48
2
8
17

Bottom 
TABLE III (continued).

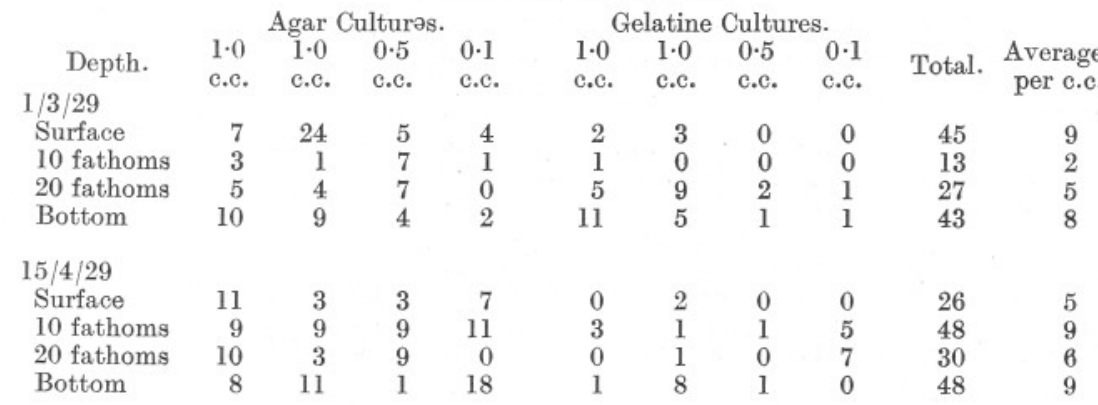

\section{Summary of Table III. Loch Long.}

Depth.

Surface

10 fathoms

20 fathoms

Bottom
Total No. of bacteria counted.

$$
\begin{array}{r}
1740 \\
1198 \\
264
\end{array}
$$$$
448
$$

Average per c.c.

$$
\begin{array}{r}
39 \\
27 \\
6
\end{array}
$$

\section{TABLE IV.}

\section{Greenock.}

No. of bacteria present, determined by colony counts of plate cultures incubated 5 days at room temperature.

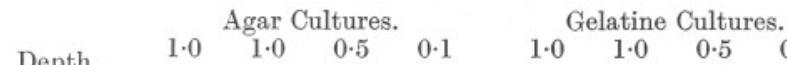

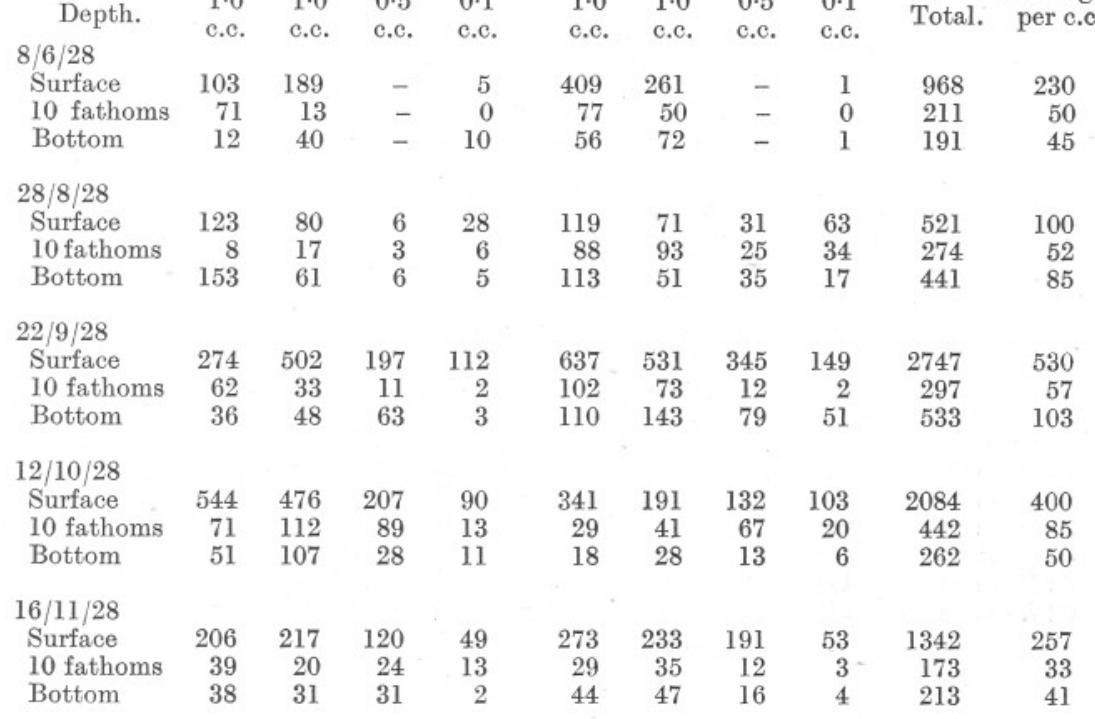


TABLE IV (continued).

\begin{tabular}{lrrrrrrrrrr} 
& \multicolumn{1}{c}{ Agar Cultures. } & \multicolumn{8}{c}{ Gelatine Cultures. } \\
\multicolumn{1}{c}{ Depth. } & $1 \cdot 0$ & $1 \cdot 0$ & $0 \cdot 5$ & $0 \cdot 1$ & $1 \cdot 0$ & $1 \cdot 0$ & $0 \cdot 5$ & $0 \cdot 1$ & \\
$7 / 12 / 28$ & c.c. & c.c. & c.c. & c.c. & c.c. & c.c. & c.c. & c.c. & Total. & \\
Average & per c.c. \\
Surface & 121 & 70 & 51 & 12 & 326 & 131 & 49 & 21 & 781 & 150 \\
10 fathoms & 67 & 51 & 21 & 5 & 47 & 41 & 33 & 4 & 269 & 52 \\
Bottom & 113 & 70 & 51 & 9 & 71 & 29 & 12 & 11 & 367 & 71
\end{tabular}

$\begin{array}{lrrrrrrrrrr}25 / 1 / 29 & & & & & & & & & & \\ \text { Surface } & 49 & 46 & 36 & 5 & 88 & 139 & 29 & 1 & 393 & 75 \\ 10 \text { fathoms } & 69 & 119 & 69 & 19 & 63 & 130 & 39 & 13 & 521 & 100 \\ \text { Bottom } & 18 & 17 & 4 & 0 & 8 & 11 & 6 & 0 & 64 & 12 \\ & & & & & & & & & & \\ 22 / 2 / 29 & & & & & & & & & & \\ \quad \text { Surface } & 401 & 317 & 91 & 35 & 177 & 210 & 23 & 7 & 1261 & 243 \\ \quad 10 \text { fathoms } & 79 & 91 & 40 & 9 & 154 & 115 & 70 & 0 & 558 & 130 \\ \text { Bottom } & 94 & 61 & 24 & 10 & 81 & 207 & 73 & 9 & 559 & 130 \\ & & & & & & & & & & \\ 1 / 3 / 29 & & & & & & & & & & \\ \quad \text { Surface } & 76 & 201 & 153 & 71 & 89 & 331 & 71 & 41 & 1033 & 198 \\ 10 \text { fathoms } & 36 & 119 & 139 & 25 & 18 & 17 & 101 & 24 & 480 & 92 \\ \text { Bottom } & 101 & 91 & 28 & 2 & 30 & 27 & 91 & 141 & 511 & 98 \\ \quad & & & & & & & & & & \\ \text { 15/4/29 } & & & & & & & & & & \\ \text { Surface } & 229 & 89 & 23 & 8 & 109 & 6 & 0 & 0 & 464 & 90 \\ \text { 10 fathoms } & 123 & 41 & 29 & 7 & 110 & 11 & 0 & 3 & 324 & 62 \\ \text { Bottom } & 207 & 22 & 9 & 17 & 140 & 2 & 3 & 0 & 400 & 77 \\ & & & & & & & & & & \end{array}$

\section{Summary of Table IV. Greenock.}

Total No. of

Depth. bacteria counted. Average per c.c.

$\begin{array}{lrr}\text { Surface } & 10,626 & 240 \\ 10 \text { fathoms } & 3,338 & 71 \\ \text { Bottom } & 3,340 & 71\end{array}$

TABLE V.

\section{Cumbrae Deep.}

\begin{tabular}{lrrrrrrrrr} 
& \multicolumn{1}{c}{ Agar Cultures. } & \multicolumn{9}{c}{ Gelatine Cultures. } & & \\
\multicolumn{1}{c}{ Depth. } & \multicolumn{1}{c}{$1 \cdot 0$} & $0 \cdot 5$ & $0 \cdot 1$ & \multicolumn{1}{c}{$1 \cdot 0$} & $0 \cdot 5$ & $0 \cdot 1$ & Total. & Average \\
per c.c.
\end{tabular}




\section{TABLE VI.}

Quantitative Bacterial Analyses of Littoral Surface Samples taken in the Fucus Zone, Cran Bight, Outside the Millport Marine Biological Station.

Date of
Sample.
$31 / 3 / 28$
$2 / 4 / 28$
$3 / 4 / 28$
$4 / 4 / 28$
$5 / 4 / 28$
$6 / 4 / 28$
$7 / 4 / 28$
$8 / 4 / 28$
$9 / 4 / 28$
$10 / 4 / 28$
$11 / 4 / 28$

\begin{tabular}{rrrrrc}
\multicolumn{7}{c}{ Agar Cultures. } & & & Average \\
$1 \cdot 0$ c.c. & $1 \cdot 0$ c.c. & $0 \cdot 1$ c.c. & $0 \cdot 01$ c.c. & Total. & per c.c. \\
442 & 457 & 91 & 0 & 990 & 470 \\
$\infty$ & 227 & 181 & 227 & 408 & $>500$ \\
238 & 104 & 101 & 8 & 451 & 210 \\
201 & - & 15 & 5 & 221 & 220 \\
130 & - & 44 & 0 & 174 & 170 \\
521 & 479 & 71 & 1 & 1072 & 550 \\
89 & 198 & 21 & 0 & 308 & 150 \\
514 & 347 & 66 & - & 927 & 440 \\
193 & 85 & 10 & 10 & 298 & 140 \\
503 & 200 & - & - & 703 & 350 \\
371 & 366 & - & - & 737 & 370
\end{tabular}

Approximate mean average number of bacteria per c.c. $=500$.

\section{TABLE VII}

Quantitative Bacterial Analyses of Surface Samples taken from an Enteromorpha Pool Outside the Millport Marine Biological Station.

\begin{tabular}{rcccccc} 
Date of & \multicolumn{7}{c}{ Agar Cultures. } & & Average \\
Sample. & $0 \cdot 1$ c.c. & $0 \cdot 1$ c.c. & $0 \cdot 01$ c.c. & $0 \cdot 01$ c.c. & Total. & per c.c. \\
$31 / 3 / 28$ & 494 & 593 & 61 & 27 & 1175 & 5300 \\
$2 / 4 / 28$ & 731 & 448 & 59 & 73 & 1311 & 6000 \\
$3 / 4 / 28$ & 728 & 568 & 81 & 35 & 1412 & 6400 \\
$4 / 4 / 28$ & 381 & 473 & 51 & 92 & 997 & 4600 \\
$5 / 4 / 28$ & 640 & 341 & 49 & 50 & 1080 & 4900 \\
$6 / 4 / 28$ & 760 & 451 & 60 & 81 & 1352 & 6100 \\
$7 / 4 / 28$ & 331 & 307 & 52 & 70 & 760 & 3500 \\
$8 / 4 / 28$ & 800 & 488 & 60 & 23 & 1371 & 6200 \\
$9 / 4 / 28$ & 411 & 571 & 21 & 82 & 1085 & 4900 \\
$10 / 4 / 28$ & 566 & 498 & 20 & 27 & 1111 & 5000 \\
$11 / 4 / 28$ & 470 & 403 & 21 & 72 & 966 & 4400
\end{tabular}

Approximate mean average number of bacteria per c.c. $=5200$. 
